\title{
PENGGUNAAN UANG ELEKTRONIK DAN UANG VIRTUAL SEBAGAI PENGGANTI UANG TUNAI DI INDONESIA
}

\author{
Decky Hendarsyah \\ Sekolah Tinggi Ilmu Ekonomi (STIE) Syariah Bengkalis \\ J1. Poros Sungai Alam - Selat Baru, Sungai Alam, Bengkalis, Riau \\ Email:deckydb@gmail.com
}

\begin{abstract}
Abstrak
Teknologi informasi sangatlah pesat perkembangannya, sehingga merubah sebagian besar gaya hidup masyarakat terutama di Indonesia yang awalnya bersifat tradisional menjadi moderen. Dunia perbankan saat ini juga sudah memanfaatkan teknologi informasi dalam operasionalnya sehari-hari, dimana operasionalnya dikenal dengan Sistem Aplikasi Perbankan. Dengan pemanfaatan teknologi informasi operasional bank semakin hari semakin efektif dan efisien serta menyediakan fasilitas-fasilitas pendukung yang mempermudah transaksi keuangan bagi nasabah seperti fasilitas pembayaran non tunai. Penggunaan teknologi modern sebagai instrument pembayaran non tunai, baik secara domestik maupun secara internasional, telah berkembang pesat disertai dengan berbagai inovasi yang mengarah pada penggunaan yang semakin efisien, praktis, aman, cepat dan nyaman. Fasilitas pembayaran non tunai tersebut akhir-akhir ini muncul dalam bentuk instrument pembayaran yang dikenal dengan uang elektronik (electronic money/e-money) dan uang virtual (virtual money). Untuk itu dalam tulisan ini akan lebih membahas dan memperjelas secara mendalam tentang penggunaan uang elektronik dan uang virtual sebagai pengganti uang tunai di Indonesia. Sehingga masyarakat akan lebih mengetahui perkembangan, jenis-jenis dan manfaat serta kelebihan dan kekurangan uang elektronik dan uang virtual dibandingkan dengan uang tunai.
\end{abstract}

Kata Kunci: Uang Elektronik, Uang Virtual, Uang Tunai, Non Tunai

\section{Pendahuluan}

Perkembangan teknologi informasi telah merubah sebagian besar gaya hidup masyarakat Indonesia mulai dari perdesaan sampai ke perkotaan. Masyarakat saat ini lebih cendrung menggunakan perangkat telepon pintar (smartphone) dalam kehidupan sehari-hari. Bisa dilihat hampir setiap saat orang menggunakan telepon pintar untuk berinteraksi dan berkomunikasi, baik melalui saluran seluler maupun menggunakan sosial media. Hampir semua kegiatan sehari-hari tidak terlepas dari telepon pintar, karena sudah terhubung dengan Internet. Kegiatan yang dilakukan masyakarat menggunakan telepon pintar mulai dari sekedar menelepon atau sms, berbincang di sosial media, berbisnis dan melakukan transaksi keuangan secara online.

Dewasa ini dunia perbankan sudah memanfaatkan teknologi informasi dalam operasional perbankan sehari-hari yang dikenal dengan Sistem Aplikasi Perbankan. Penerapan teknologi informasi di bidang perbankan tersebut 
diharapkan memberikan keunggulan komparatif untuk setiap Bank sehingga produk dan jasanya relatif kompetitif di pasar. Industri perbankan di Indonesia merupakan salah satu sektor perekonomian yang mengalami perkembangan relatif paling dinamis dibandingkan sektor ekonomi yang lain, dengan sasaran mengerahkan dana masyarakat serta meningkatkan efisiensi di bidang perbankan dan lembaga keuangan.

Sebagai lembaga keuangan yang sebagian besar dananya berasal dari surplus unit, Bank dituntut untuk mengelola dana tersebut secara profesional dan terpercaya. Peranan dunia perbankan tersebut memerlukan dukungan kemampuan sumber daya manusia serta pencarian alternatif penanganan operasional Bank yang semakin efektif dan efisien serta menyediakan fasilitas-fasilitas pendukung yang mempermudah transaksi keuangan bagi nasabah seperti fasilitas pembayaran non tunai.

Pertumbuhan alat pembayaran telah meningkat begitu pesat, seiring dengan pengembangan teknologi dalam sistem pembayaran yang sedang berkembang saat ini. Penggunaan teknologi modern sebagai instrument pembayaran non tunai, baik secara domestik maupun secara internasional, telah berkembang pesat disertai dengan berbagai inovasi yang mengarah pada penggunaannya yang semakin efisien, aman, cepat dan nyaman. ${ }^{1}$

Dampak perkembangan teknologi dalam sistem pembayaran tersebut terakhir ini adalah munculnya instrument pembayaran yang dikenal dengan uang elektronik (electronic money/e-money) dan uang virtual (virtual money). Uang elektronik muncul sebagai jawaban atas kebutuhan terhadap intrumen pembayaran mikro yang diharapkan mampu melakukan proses pembayaran secara cepat dengan biaya yang relatif murah, karena nilai uang yang disimpan, instrument ini dapat ditempatkan pada suatu media tertentu yang mampu diakses dengan cepat secara off-line, aman dan murah ${ }^{2}$. Sedang uang virtual lebih ditujukan untuk transaksi keuangan online lintas Negara di Internet. Selain itu kemunculan uang elektronik juga dilatar belakangi oleh Peraturan Bank Indonesia Nomor 11/12/PBI/2009 dan Nomor 16/8/PBI/2014 sebagai salah satu pendukung agenda Bank Indonesia untuk menciptakan masyarakat mengurangi penggunaan uang tunai (less cash society) di Republik Indonesia.

Penggunaan uang elektronik sebagai alternatif alat pembayaran non tunai menunjukkan adanya potensi yang cukup besar untuk mengurangi tingkat pertumbungan penggunaan uang tunai. Uang elektronik menawarkan transaksi yang lebih cepat dan nyaman dibandingkan dengan uang tunai, khususnya untuk transaksi yang bernilai kecil, sebab dengan uang elektronik transaksi tersebut dapat dilakukan dengan lebih mudah dan murah serta menjamin keamanan dan kecepatan transaksi, baik bagi konsumen maupun bagi pedagang. ${ }^{3}$

\footnotetext{
${ }^{1}$ Burhanuddin Abdullah, 2006, Paper Seminar Internasional Toward a Less Cash Society in Indonesia, Jakarta: Direktorat Akunting dan Sistem Pembayaran Bank Indonesia, hal. 9.

${ }^{2}$ Tim Inisiatif Bank Indonesia, 2006, Working Paper: Upaya Meningkatkan Penggunaan Alat Pembayaran Non Tunai Melalui Pengembangan E-Money, Jakarta: BI, hal. 8.

${ }^{3}$ Siti Hidayati, dkk., 2006, Operasional E-Money, Jakarta: BI, hal. 1.
} 


\section{Uang Elektronik}

Dalam laporan uang elektronik Bank Sentral Eropa menyebutkan bahwa uang elektronik secara luas didefinisikan sebagai sebuah toko moneter elektronik yang memiliki nilai pada perangkat teknis yang dapat digunakan secara luas untuk melakukan pembayaran usaha dan keperluan lainnya tanpa harus melibatkan rekening bank dalam setiap transaksinya, tetapi bertindak sebagai instrumen prabayar. ${ }^{4}$

Uang elektronik adalah alat pembayaran elektronik yang diperoleh dengan menyetorkan terlebih dahulu sejumlah uang kepada penerbit, baik secara langsung, maupun melalui agen-agen penerbit, atau dengan pendebitan rekening di bank dan nilai uang tersebut dimasukkan menjadi nilai uang dalam media uang elektronik, yang dinyatakan dalam satuan Rupiah, yang digunakan untuk melakukan transaksi pembayaran dengan cara mengurangi secara langsung nilai uang pada media uang elektronik tersebut. ${ }^{5}$

Sedangkan menurut situs bank-indo.com yang ditulis oleh Septiano Pratama mengatakan bahwa uang elektronik adalah uang yang disimpan menggunakan suatu chip atau biasa dikenal RFID (Radio Frequency Identification) dan terkoneksi dengan jaringan komputer dan Internet. Cara melakukan transaksi dengan uang elektronik ialah dengan menempelkan kartu yang merupakan bentuk dari uang elektronik tersebut pada alat yang bernama EDC (Electronic Data Capture). Kartu yang berfungsi sebagai pengganti uang Anda sudah tertanam sebuah chip RFID yang disebutkan diawal dan terkoneksi dengan jaringan komputer dan Internet, sebagai penyimpanan media digitalnya menggunakan EFT (Electronic Funds Transfer). ${ }^{6}$

Dalam Peraturan Bank Indonesia Nomor 16/8/PBI/2014 pada pasal 1 ayat 3 dan 4 menyebutkan bahwa Uang Elektronik (Electronic Money) adalah alat pembayaran yang memenuhi unsur-unsur sebagai berikut:

a. diterbitkan atas dasar nilai uang yang disetor terlebih dahulu kepada penerbit;

b. nilai uang disimpan secara elektronik dalam suatu media server atau chip;

c. digunakan sebagai alat pembayaran kepada pedagang yang bukan merupakan penerbit uang elektronik tersebut; dan

d. nilai uang elektronik yang dikelola oleh penerbit bukan merupakan simpanan sebagaimana dimaksud dalam undang-undang yang mengatur mengenai perbankan.

\footnotetext{
${ }^{4}$ European Central Bank, 1998, Report On Electronic Money, Frankfurt: European Central Bank, hal. 7.

${ }^{5}$ Veithal Rivai, dkk., 2001, Bank and Financial Institution Management, Jakarta: PT. Raja Grafindo Persada, hal 1367.

${ }^{6}$ Septiano Pratama, "Menggunakan Mesin Pencari Google dengan kata kunci uang elektronik" dalam http://www.bank-indo.com/pengertian-uang-elektronik-dan-macam-bank-penyedianya/. Diakses tanggal 17 Maret 2016.
} 
Nilai Uang Elektronik adalah nilai uang yang disimpan secara elektronik pada suatu media server atau chip yang dapat dipindahkan untuk kepentingan transaksi pembayaran dan/atau transfer dana. ${ }^{7}$

\section{Jenis-Jenis Uang Elektronik}

Pada situs finance.detik.com Dewi Rachmat Kusuma mengatakan bahwa Bank Indonesia menetapkan dua jenis uang elektronik berdasarkan bentuk yaitu berbentuk kartu dan ponsel. ${ }^{8}$

Berdasarkan masa berlaku uang elektronik maka uang elektronik dibedakan menjadi dua jenis yaitu: ${ }^{9}$

a. Reloadable: adalah uang elektronik yang dapat dilakukan pengisian ulang, dengan kata lain, apabila masa berlakunya sudah habis dan atau nilai uang elektroniknya sudah habis terpakai, maka uang elektronik tersebut dapat digunakan kembali untuk dilakukan pengisian ulang.

b. Disposable: adalah uang elektronik yang tidak dapat diisi ulang, apabila masa berlakunya sudah habis dan atau nilai uang elektroniknya sudah habis terpakai, maka uang elektronik tersebut tidak dapat digunakan kembali untuk dilakukan pengisian ulang.

Sedangkan jenis-jenis uang elektronik menurut Peraturan Bank Indonesia Nomor 16/8/PBI/2014 pada pasal $1 \mathrm{~A}$ ayat 1 sampai 3 menyebutkan bahwa berdasarkan pencatatan data identitas pemegang, uang elektronik dapat dibedakan menjadi 2 (dua) jenis, yaitu:

a. Uang elektronik yang data identitas pemegangnya terdaftar dan tercatat pada penerbit (registered).

b. Uang elektronik yang data identitas pemegangnya tidak terdaftar dan tidak tercatat pada penerbit (unregistered).

Fasilitas yang dapat diberikan oleh penerbit jenis uang elektronik registered adalah berupa:

- registrasi pemegang;

- pengisian ulang (top up);

- pembayaran transaksi;

- pembayaran tagihan;

- transfer dana;

- tarik tunai;

- penyaluran program bantuan pemerintah kepada masyarakat; dan/atau

- fasilitas lain berdasarkan persetujuan Bank Indonesia.

Fasilitas yang dapat diberikan oleh penerbit jenis uang elektronik unregistered adalah berupa:

- pengisian ulang (top up);

\footnotetext{
${ }^{7}$ Peraturan Bank Indonesia Nomor 16/8/PBI/2014, Tentang Perubahan Atas Peraturan Bank Indonesia Nomor 11/12/PBI/2009 Tentang Uang Elekronik (Electronic Money) Pasal 1 ayat 3 dan 4.

${ }^{8}$ Dewi Rachmat Kusuma, "Menggunakan Mesin Pencari Google dengan kata kunci uang elektronik" dalam http://finance.detik.com/read/2014/08/20/180359/2667868/5/masyarakat-bisapakai-uang-elektronik-maksimal-rp-20-juta-sebulan. Diakses tanggal 19 Maret 2016.

Surat Edaran Bank Indonesia Nomor 11/11/DASP, Perihal Uang Elektronik, (Jakarta: BI, tertanggal 13 April 2009), hal.27.
} 
- pembayaran transaksi;

- pembayaran tagihan;

- fasilitas lain berdasarkan persetujuan Bank Indonesia. ${ }^{10}$

\section{Penerbit Uang Elektronik Di Indonesia}

Pada situs bi.go.id menyebutkan bahwa penerbit uang elektronik di Indonesia yang terdaftar pada Bank Indonesia adalah sebagai berikut: ${ }^{11}$

\section{Tabel 1. Penerbit Uang Elektronik Di Indonesia}

\begin{tabular}{|c|c|c|c|}
\hline No. & Nama Penerbit / Tanggal Operasi ${ }^{12}$ & $\begin{array}{c}\text { Nama Produk } \\
\text { Uang Elektronik }\end{array}$ & Keterangan \\
\hline 1 & $\begin{array}{l}\text { BPD DKI JAKARTA } \\
3 \text { Juli } 2009\end{array}$ & Jak Card (Kartu) & $\begin{array}{l}\text { Kartu Perdana: Rp. 20.000,-- } \\
\text { Saldo Minimum: Tanpa Batasan } \\
\text { Saldo Maksimal: Rp. } 1 \text { Juta }\end{array}$ \\
\hline 2 & $\begin{array}{l}\text { BANK MANDIRI } \\
3 \text { Juli } 2009\end{array}$ & $\begin{array}{l}\text { e-Cash (Ponsel) } \\
\text { e-Money dan e- } \\
\text { Tollpass (Kartu) }\end{array}$ & $\begin{array}{l}\text { Uang Tunai di Ponsel } \\
\text { Saldo Minimum: Tanpa Batasan } \\
\text { Saldo Maksimal: Rp. } 1 \text { Juta } \\
\text { Rp. } 5 \text { Juta } \\
\text { Penutupan Kartu: Rp. 5.000,- } \\
\text { Saldo Minimum: Tanpa Batasan } \\
\text { Saldo Maksimal: Rp. 1 Juta }\end{array}$ \\
\hline 3 & $\begin{array}{l}\text { BANK CENTRAL ASIA } \\
3 \text { Juli } 2009\end{array}$ & $\begin{array}{l}\text { Sakuku (Ponsel) } \\
\text { DUITT (Ponsel) } \\
\text { Flazz (Kartu) }\end{array}$ & $\begin{array}{l}\text { Uang Tunai di Ponsel } \\
\text { Saldo Minimum: Tanpa Batasan } \\
\text { Saldo Maksimal: Rp. } 1 \text { Juta } \\
\text { Rp. } 5 \text { Juta } \\
\text { Uang Tunai di Ponsel } \\
\text { Saldo Minimum: Tanpa Batasan } \\
\text { Saldo Maksimal: Rp. } 1 \text { Juta } \\
\text { Rp. } 5 \text { Juta } \\
\text { Isi ulang minimum: Rp. 20.000,- } \\
\text { Saldo Minimum: Tanpa Batasan } \\
\text { Saldo Maksimal: Rp. 1 Juta }\end{array}$ \\
\hline 4 & $\begin{array}{l}\text { PT. TELEKOMUNIKASI INDONESIA } \\
3 \text { Juli } 2009\end{array}$ & $\begin{array}{l}\text { t-money (Ponsel dan } \\
\text { Kartu) }\end{array}$ & $\begin{array}{l}\text { Kartu Perdana: Rp. } 100.000,- \\
\text { Isi ulang minimum: Rp. } 2.000,-\end{array}$ \\
\hline 5 & $\begin{array}{l}\text { PT. TELEKOMUNIKASI SELULAR } \\
3 \text { Juli } 2009\end{array}$ & tcash (Ponsel) & $\begin{array}{c}\text { Saldo Minimum: Tanpa Batasan } \\
\text { Saldo Maksimal: Rp. } 1 \text { Juta } \\
\text { Rp. } 5 \text { Juta }\end{array}$ \\
\hline 6 & $\begin{array}{l}\text { BANK MEGA } \\
3 \text { Juli } 2009\end{array}$ & $\begin{array}{l}\text { MegaMobile (Ponsel) } \\
\text { MegaCash (Kartu) }\end{array}$ & $\begin{array}{ll}- \\
- \\
-\end{array}$ \\
\hline 7 & $\begin{array}{l}\text { PT. SKYE SAB INDONESIA } \\
3 \text { Juli } 2009\end{array}$ & $\begin{array}{l}\text { SKYE Mobile Money } \\
\text { (Ponsel) }\end{array}$ & $\begin{array}{r}\text { Saldo Maksimal: Rp. } 1 \text { Juta } \\
\text { Rp. } 5 \text { Juta }\end{array}$ \\
\hline
\end{tabular}

\footnotetext{
${ }^{10}$ Peraturan Bank Indonesia Nomor 16/8/PBI/2014, Tentang Perubahan Atas Peraturan Bank Indonesia Nomor 11/12/PBI/2009 Tentang Uang Elekronik (Electronic Money) Pasal 1A ayat 1 sampai 3.

${ }^{11}$ http://www.bi.go.id/id/statistik/sistem-pembayaran/uang-

elektronik/contents/penyelenggara\%20uang\%20 elektronik.aspx. Diakses tanggal 21 Maret 2016. http://www.bi.go.id/id/sistem-pembayaran/informasi-perizinan/uangelektronik/Contents/Default.aspx. Diakses tanggal 23 Maret 2016.
} 


\begin{tabular}{|c|c|c|c|}
\hline 8 & $\begin{array}{l}\text { PT. INDOSAT } \\
3 \text { Juli } 2009\end{array}$ & Dompetku (Ponsel) & Saldo Maksimal: Rp. 5 Juta \\
\hline 9 & $\begin{array}{l}\text { BANK NEGARA INDONESIA } \\
\text { 3 Juli } 2009\end{array}$ & TapCash (Kartu) & $\begin{array}{l}\text { Tanpa Transaksi Minimum } \\
\text { Saldo Maksimal: Rp. } 1 \text { Juta }\end{array}$ \\
\hline 10 & $\begin{array}{l}\text { BANK RAKYAT INDONESIA } \\
29 \text { Desember } 2010\end{array}$ & $\begin{array}{l}\text { Brizzi (Kartu) } \\
\text { MoCash (Ponsel) }\end{array}$ & Saldo Maksimal: Rp. 1 Juta \\
\hline 11 & $\begin{array}{l}\text { PT. XL AXIATA } \\
29 \text { Maret } 2011\end{array}$ & XL Tunai (Ponsel) & $\begin{array}{r}\text { Saldo Maksimal: Rp. } 1 \text { Juta } \\
\text { Rp. } 5 \text { Juta }\end{array}$ \\
\hline 12 & $\begin{array}{l}\text { PT. FINNET INDONESIA } \\
1 \text { Juni } 2012\end{array}$ & $\begin{array}{l}\text { t-money (Ponsel dan } \\
\text { Kartu) }\end{array}$ & $\begin{array}{l}\text { Kartu Perdana: Rp. 100.000,- } \\
\text { Isi ulang minimum: Rp. } 2.000,-\end{array}$ \\
\hline 13 & $\begin{array}{l}\text { PT. ARTAJASA PEMBAYARAN } \\
\text { ELEKTRONIS } \\
21 \text { November } 2012\end{array}$ & ARTAJASA & - \\
\hline 14 & $\begin{array}{l}\text { BANK PERMATA } \\
\text { 23 Januari } 2013\end{array}$ & $\begin{array}{l}\text { BBM Money } \\
\text { (Ponsel) }\end{array}$ & $\begin{array}{r}\text { Saldo Maksimal: Rp. } 1 \text { Juta } \\
\text { Rp. } 5 \text { Juta }\end{array}$ \\
\hline 15 & $\begin{array}{l}\text { BANK CIMB NIAGA } \\
27 \text { Maret } 2013\end{array}$ & $\begin{array}{l}\text { Rekening Ponsel } \\
\text { (Ponsel) }\end{array}$ & $\begin{array}{r}\text { Saldo Maksimal: Rp. } 1 \text { Juta } \\
\text { Rp. } 5 \text { Juta }\end{array}$ \\
\hline 16 & $\begin{array}{l}\text { PT. NUSA SATU INTI ARTHA } \\
25 \text { Maret } 2013\end{array}$ & DokuPay & - \\
\hline 17 & $\begin{array}{l}\text { PT. BANK NATIONALNOBU } \\
29 \text { April } 2013\end{array}$ & $\begin{array}{l}\text { Nobu e-Money } \\
\text { (Kartu) } \\
\text { Nobu Pay (Ponsel) }\end{array}$ & $\begin{array}{l}\text { Saldo Maksimal: Rp. } 1 \text { Juta } \\
\text { Saldo Maksimal: Rp. } 1 \text { Juta }\end{array}$ \\
\hline 18 & $\begin{array}{l}\text { PT. SMARTFREN TELECOM } \\
16 \text { Juni } 2014\end{array}$ & Uangku (Ponsel) & $\begin{array}{r}\text { Saldo Maksimal: Rp. } 1 \text { Juta } \\
\text { Rp. } 5 \text { Juta }\end{array}$ \\
\hline 19 & $\begin{array}{l}\text { PT. MVCOMMERCE INDONESIA } \\
29 \text { September } 2014\end{array}$ & PonselPay (Ponsel) & - \\
\hline 20 & $\begin{array}{l}\text { PT. WITAMI TUNAI MANDIRI } \\
5 \text { Januari } 2015\end{array}$ & truemoney (Ponsel) & $\begin{array}{l}\text { Setoran Awal: Rp. } 20.000,- \\
\text { Setoran Minimum: Rp. 20.000,- } \\
\text { Saldo Maksimal: Rp. } 1 \text { Juta } \\
\text { Rp. } 5 \text { Juta }\end{array}$ \\
\hline
\end{tabular}

Dalam situs finance.detik.com menjelaskan bahwa Direktur Eksekutif Departemen Pengembangan Akses Keuangan dan UMKM BI Eni Panggabean mengatakan, masyarakat dianjurkan untuk menggunakan uang elektronik dalam melakukan transaksi. Maksimal penggunaan uang elektronik ini yaitu Rp 5 juta per hari per orang atau secara kumulatif maksimal mencapai Rp 20 juta per orang setiap bulannya. Dia menambahkan, masyarakat juga bisa memilih jenis uang elektronik, ada yang registered dan non registered. Bedanya, saldo uang elektronik registered jumlahnya bisa mencapai $\mathrm{Rp} 5$ juta, sementara non registered dibatasi hanya $\mathrm{Rp} 1$ juta. ${ }^{13}$ Setiap produk-produk uang elektronik yang diterbitkan mempunyai merchant-merchant tersendiri tergantung kerjasama yang telah dilakukan oleh penerbit uang elektronik tersebut dengan pihak ketiga baik

${ }^{13}$ Dewi Rachmat Kusuma, Op.cit. 
dalam bentuk kartu maupun ponsel. Sebagai contoh: e-Tollpass merupakan kartu yang digunakan sebagai alat pembayaran untuk masuk jalan tol secara non tunai, kemudian Flazz, TapCash dan Brizzi merupakan kartu yang digunakan untuk belanja non tunai pada merchant tertentu.

\section{Perkembangan Penggunaan Uang Elektronik Di Indonesia}

Perkembangan penggunaan uang elekronik di Indonesia dari tahun ke tahun semakin meningkat secara signifikan, peningkatan ini dapat diperhatikan dari angka-angka uang elekronik yang beredar seperti ditunjukan pada Tabel 2. Pada Tabel 2 dapat dilihat pada tahun 2014 dan 2015 ada penurunan yang tidak terlalu signifikan terhadap peredaran uang elektronik. Kemudian perkembangan penggunaan uang elekronik di Indonesia juga bisa dilihat dari transaksi yang telah dilakukan seperti yang terlihat pada Tabel 3. Pada Tabel 3 dapat diperhatikan bahwa transaksi uang elektronik baik jumlah transaksinya maupun jumlah nominal uang elektronik meningkat sangat signifikan. Dengan berkembangnya penggunaan uang elektronik maka infrastruktur uang elektronik juga mengalami kenaikan setiap tahunnya seperti yang terlihat pada Tabel 4. Pada Tabel 3 dapat dilihat kebutuhan akan mesin reader untuk membaca uang elektronik makin meningkat.

Tabel 2. Jumlah Uang Elektronik
\begin{tabular}{|c|r|}
\hline Tahun & Jumlah \\
\hline 2008 & 430.801 \\
\hline 2009 & 3.016 .272 \\
\hline 2010 & 7.914 .018 \\
\hline 2011 & 14.299 .726 \\
\hline 2012 & 21.869 .946 \\
\hline 2013 & 36.225 .373 \\
\hline 2014 & 35.738 .233 \\
\hline 2015 & 34.314 .795 \\
\hline Feb-2016 & 35.876 .523 \\
\hline
\end{tabular}

Tabel 3. Transaksi Uang Elektronik ${ }^{15}$

\begin{tabular}{|c|r|r|}
\hline Tahun & $\begin{array}{c}\text { Volume } \\
\text { (Transaksi) }\end{array}$ & $\begin{array}{c}\text { Nominal } \\
\text { (Dalam Juta Rupiah) }\end{array}$ \\
\hline 2008 & 2.560 .591 & 76.675 \\
\hline 2009 & 17.436 .631 & 519.213 \\
\hline 2010 & 26.541 .982 & 693.467 \\
\hline 2011 & 41.060 .149 & 981.297 \\
\hline
\end{tabular}

\footnotetext{
14 http://www.bi.go.id/id/statistik/sistem-pembayaran / uang - elektronik / contents / jumlah \% 20uang\%20 elektronik.aspx. Diakses tanggal 23 Maret 2016.

15 http://www.bi.go.id/id/statistik/sistem-pembayaran/uang-elektronik/contents/transaksi.aspx. Diakses tanggal 23 Maret 2016.
} 


\begin{tabular}{|c|r|r|}
\hline 2012 & 100.623 .916 & 1.971 .550 \\
\hline 2013 & 137.900 .779 & 2.907 .432 \\
\hline 2014 & 203.369 .990 & 3.319 .556 \\
\hline 2015 & 485.829 .054 & 4.783 .422 \\
\hline Feb-2016 & 87.880 .556 & 906.769 \\
\hline
\end{tabular}

Tabel 4. Infrastruktur Uang Elektronik ${ }^{16}$

\begin{tabular}{|c|c|}
\hline Tahun & Mesin Reader (Unit) \\
\hline 2013 & 139.157 \\
\hline 2014 & 206.826 \\
\hline 2015 & 281.988 \\
\hline Feb-2016 & 296.705 \\
\hline
\end{tabular}

\section{Perbedaan Uang Elektronik Dengan Alat Pembayaran Menggunakan Kartu $^{17}$}

Uang elektronik memiliki karakteristik yang berbeda dengan alat pembayaran menggunakan kartu seperti kartu kredit, charge card dan kartu debit atau ATM. Secara umum perbedaan antara uang elektronik dengan alat pembayaran menggunakan kartu lainnya adalah sebagai berikut:

Tabel 5. Perbedaan Uang Elektronik Dengan Alat Pembayaran Menggunakan Kartu

\begin{tabular}{|c|l|l|}
\hline No. & Uang Elektronik & Alat Pembayaran Menggunakan Kartu \\
\hline 1 & $\begin{array}{l}\text { Nilai uang tercatat dalam instrument } \\
\text { media uang elektronik }\end{array}$ & $\begin{array}{l}\text { Tidak ada pencatatan nilai uang pada } \\
\text { intrumen kartu }\end{array}$ \\
\hline 2 & $\begin{array}{l}\text { Dana sepenuhnya berada dalam } \\
\text { penguasaan pemegang }\end{array}$ & $\begin{array}{l}\text { Dana sepenuhnya berada dalam penguasaan } \\
\text { bank }\end{array}$ \\
\hline 3 & $\begin{array}{l}\text { Transaksi pembayaran dilakukan } \\
\text { secara offline ke penerbit }\end{array}$ & $\begin{array}{l}\text { Transaksi pembayaran dilakukan secara } \\
\text { online ke penerbit }\end{array}$ \\
\hline
\end{tabular}

\section{Manfaat Uang Elektronik}

Dalam perekonomian modern lalu lintas pertukaran barang dan jasa sudah sedemikian cepatnya sehingga memerlukan dukungan tersedianya sistim pembayaran yang handal yang memungkinkan dilakukannya pembayaran secara lebih cepat, efisien, dan aman. Penggunaan uang tunai sebagai alat pembayaran dirasakan mulai menimbulkan masalah, terutama tingginya biaya transaksi uang tunai dan rendahnya perputaran uang. ${ }^{18}$

Kebutuhan instrument pembayaran mikro muncul karena apabila pembayaran dilakukan menggunakan intrumen pembayaran lain yang ada saat ini, misalnya uang tunai, kartu debit, kartu kredit dan sebagainya menjadi tidak praktis dan

\footnotetext{
${ }^{16}$ http://www.bi.go.id/id/statistik/sistem-pembayaran/uang-

elektronik/contents/infrastrukturuangelektronik. aspx. Diakses tanggal 23 Maret 2016.

${ }^{17}$ Siti Hidayati, dkk., Op.cit., hal. 4.

${ }^{18}$ Tim Inisiatif Bank Indonesia, 2006, Op.cit., hal.2.
} 
efisien. Uang elekrtonik muncul sebagai jawaban atas kebutuhan terhadap instrument pembayaran mikro yang diharapkan mampu melakukan proses pembayaran secara cepat dengan biaya yang relatif murah karena pada umumnya nilai uang yang disimpan instrument ini ditempatkan pada suatu tempat tertentu yang mampu diakses cepat secara offline, aman dan murah. ${ }^{19}$

Dari penjelasan yang telah disebutkan di atas maka manfaat uang elektronik dapat ditambahkan dan dirangkum dari segi pandang berbagai aspek diantaranya adalah:

a. Lebih praktis, cepat, fleksibel dan nyaman dibandingkan dengan uang tunai, khususnya untuk transaksi yang bernilai kecil, disebabkan nasabah tidak perlu menyediakan sejumlah uang pas untuk suatu transaksi atau harus menyimpan uang kembalian.

b. Uang elektronik dapat diisi ulang melalui berbagai sarana yang disediakan oleh penerbit.

c. Tingkat kepuasan konsumen yang semakin bertambah dengan berkurangnya biaya transaksi.

d. Adanya sumber pendapatan bagi penyedia jasa pembayaran non tunai.

e. Uang elektronik mudah didapatkan dan digunakan.

f. Uang elektronik lebih menjamin kepastian dan perlindungan hak konsumen.

g. Waktu yang diperlukan untuk menyelesaikan suatu transaksi dengan uang elektronik dapat dilakukan jauh lebih singkat dibandingkan transaksi dengan kartu kredit atau kartu debit, karena tidak harus memerlukan otorisasi on-line, tanda tangan maupun PIN.

h. Selain menghemat uang kembalian, uang elektronik juga mendorong orang untuk berhemat dengan cara bijak memperhitungkan pengeluaran.

i. Mendapatkan pelayanan khusus seperti potongan harga lebih besar, merchandise hingga promo-promo menguntungkan lainnya.

j. Menggunakan uang elektronik adalah bentuk andil dan peran serta warga negara dalam mendukung program pemerintah mewujudkan less cash society.

\section{Uang Virtual}

Uang virtual adalah rekening untuk menampung uang secara virtual yang digunakan sebagai alat pembayaran transaksi keuangan di Internet tanpa batas wilayah atau negara, seperti: berbelanja online, kegiatan forex, trading online dan sebagainya. Uang virtual diterbitkan oleh penerbit yang bisa berasal dari Negara mana saja, kemudian membuka kantor regional di Negara lain dan bekerjasama dengan agen-agen, reseller dan merchant atau pedagang uang virtual dari Negara lainnya. Agen-agen, reseller dan merchant tersebut melakukan deposit uang sesuai dengan kesepakatan sebagai modal usaha uang virtual. Kemudian pelanggan dari suatu Negara dapat menukarkan mata uang Negeranya melalui transfer uang kerekening bank yang dipunyai oleh para agen atau reseller uang virtual pada Negara yang sama dengan pelanggan, dan mempunyai nilai tukar seperti halnya kegiatan pada money changer. Setelah ditransfer uang melalui

\footnotetext{
${ }^{19}$ Ibid., hal. 8.
} 
rekening bank ke agen atau reseller maka masuk sejumlah uang virtual kerekening virtual sesuai dengan nilai tukar uang yang telah ditetapkan oleh agen atau reseller.

Uang virtual yang digunakan oleh penerbit kebanyakan menggunakan satuan mata uang Dollar dan ada yang menggunakan Euro sebagai pilihan kedua. Ketika pelanggan ingin mencairkan uang virtualnya menjadi uang lokal Negaranya tinggal melakukan penarikan pada rekening virtual atau menjual uang virtualnya melalui agen atau reseller, biasanya setelah dilakukan penarikan oleh pelanggan maka pihak penerbit membutuhkan waktu untuk mencairkan kerekening bank pelanggan.

Penerbit uang virtual ada yang tidak memiliki agen, reseller atau merchant di Indonesia, untuk itu biasanya penerbit menyedia rekening transfer melalui Visa, MasterCard dan Maestro. Sehingga para pelanggan yang ada di Indonesia bisa menukarkan uangnya melalui salah satu dari tiga rekening tersebut dan bisa menggunakan uang virtualnya di Internet. Berikut ini adalah beberapa penerbit uang virtual yang sering digunakan di Internet:

a. FasaPay (https://www.fasapay.co.id/) berasal dari Yogyakarta, Indonesia.

b. PayPal (https://www.paypal.com/) berasal dari California, Amerika.

c. Bitcoin (https://www.bitcoin.co.id/) berasal dari Bali, Indonesia.

d. Bitcoin (https://www.bitcoin.com/) diciptakan oleh Satoshi Nakamoto asal Jepang.

e. OKPay (https://www.okpay.com/) berasal dari Limassol, Cyprus.

f. WebMoney (http://www.wmtransfer.com/) berasal dari Rusia.

g. PerfectMoney (https://www.perfectmoney.is/) berasal dari Kowloon, Hongkong.

h. Neteller (https://www.neteller.com/) berasal dari Inggris.

i. UnionPay (http://www.unionpayintl.com/) berasal dari Tiongkok.

j. Payza (https://www.payza.com/) berasal dari London, Inggris.

k. Dan lain-lain.

\section{Penggunaan Uang Elektronik dan Uang Virtual}

Uang elektronik dan uang virtual dapat digunakan untuk berbagai macam keperluan transaksi keuangan sama halnya dengan uang tunai. Untuk itu perlu dirinci bagaimana uang elektronik dan uang virtual digunakan oleh pengguna seperti yang terlihat pada Tabel 6 sebagai berikut:

\section{Tabel 6. Penggunaan Uang Elektronik dan Uang Virtual}

\begin{tabular}{|c|c|}
\hline & \\
\hline $\begin{array}{l}\text { - Alat bayar untuk belanja di toko, } \\
\text { swalayan, supermarket dan grosir yang } \\
\text { menjadi merchant uang elektronik. } \\
\text { - Alat bayar untuk restoran, transportasi, } \\
\text { parkir, Listrik, PDAM, Telkom, TV } \\
\text { berlangganan dan SPBU yang menjadi } \\
\text { merchant uang elektronik. } \\
\text { - Alat bayar untuk belanja online pada } \\
\text { toko online yang menjadi merchant }\end{array}$ & $\begin{array}{l}\text { - Transfer atau kirim uang sesama } \\
\text { anggota uang virtual. } \\
\text { - Alat bayar untuk belanja online pada } \\
\text { toko online yang menjadi merchant } \\
\text { uang virtual. } \\
\text { - Sebagai rekening untuk deposit dan } \\
\text { penarikan dana pada kegiatan forex } \\
\text { dan trading online. } \\
\text { - Pembelian voucher game online. }\end{array}$ \\
\hline
\end{tabular}


uang elektronik.

- Transfer atau kirim uang.

- Tarik tunai.

- Isi pulsa ponsel dan voucher listrik.

- Alat bayar untuk masuk jalan tol, bioskop dan tempat rekreasi yang menjadi merchant uang elektronik.

\section{Perbandingan Uang Elektronik dengan Uang Virtual}

Pada prinsipnya cara kerja dan kegunaan uang virtual sama dengan uang elektronik. Untuk itu perlu ada perbandingan antara kedua uang tersebut seperti yang terlihat pada Tabel 7 di bawah ini:

Tabel 7. Perbandingan Uang Elektronik dengan Uang Virtual

\begin{tabular}{|c|c|c|}
\hline No. & Uang Eletronik & Uang Virtual \\
\hline 1 & 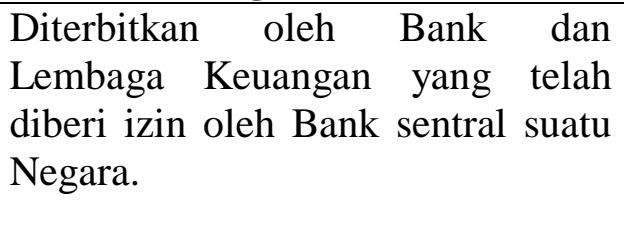 & $\begin{array}{l}\text { Diterbitkan oleh perorangan atau } \\
\text { perusahaan atau lembaga keuangan } \\
\text { (ada yang memiliki izin dari Bank } \\
\text { sentral suatu Negera dan ada juga } \\
\text { yang tidak memiliki izin). }\end{array}$ \\
\hline 2 & $\begin{array}{l}\text { Media yang digunakan kartu dan } \\
\text { ponsel. }\end{array}$ & $\begin{array}{l}\text { Ada yang menggunakan media kartu } \\
\text { dan ponsel, tapi lebih banyak } \\
\text { menggunakan aplikasi di Internet. }\end{array}$ \\
\hline 3 & $\begin{array}{l}\text { Dana sepenuhnya berada dalam } \\
\text { penguasaan pemegang. }\end{array}$ & $\begin{array}{l}\text { Dana sepenuhnya berada dalam } \\
\text { penguasaan penerbit uang virtual }\end{array}$ \\
\hline 4 & $\begin{array}{l}\text { Transaksi pembayaran dilakukan } \\
\text { secara offline ke penerbit. }\end{array}$ & $\begin{array}{l}\text { Transaksi pembayaran dilakukan } \\
\text { secara online ke penerbit. }\end{array}$ \\
\hline 5 & $\begin{array}{l}\text { Digunakan pada Negara Bank } \\
\text { penerbit kecuali ada kerjasama } \\
\text { merchant dari Negara lain. }\end{array}$ & Bisa digunakan lintas Negara \\
\hline 6 & $\begin{array}{l}\text { Menggunakan mesin reader untuk } \\
\text { membaca transaksi uang elektronik. }\end{array}$ & $\begin{array}{l}\text { Ada yang menggunakan mesin reader } \\
\text { untuk uang virtual yang memakai } \\
\text { media kartu atau ponsel, tetapi } \\
\text { kebanyakan menggunakan aplikasi } \\
\text { uang virtual di Internet. }\end{array}$ \\
\hline 7 & $\begin{array}{lll}\text { Terdapat pembatasan } & \text { saldo } \\
\text { maksimal } & \end{array}$ & $\begin{array}{l}\text { Tidak ada pembatasan saldo } \\
\text { maksimal }\end{array}$ \\
\hline 8 & $\begin{array}{l}\text { Terdapat pembatasan jumlah } \\
\text { transaksi uang harian dan bulanan }\end{array}$ & $\begin{array}{l}\text { Terdapat pembatasan } \\
\text { transaksi uang, terutama } \\
\text { penarikan saldo. }\end{array}$ \\
\hline 9 & $\begin{array}{l}\text { Tidak membutuhkan waktu lama } \\
\text { dalam penarikan saldo. }\end{array}$ & $\begin{array}{l}\text { Membutuhkan waktu dalam } \\
\text { penarikan saldo tergantung dari } \\
\text { penerbit biasanya } 1 \text { sampai } 7 \text { hari. }\end{array}$ \\
\hline 10 & $\begin{array}{l}\text { Pengisian ulang (top up) uang } \\
\text { elektronik hanya bisa dilakukan di }\end{array}$ & $\begin{array}{l}\text { Pengisian ulang (top up) uang virtual } \\
\text { bisa dilakukan dari banyak bank, }\end{array}$ \\
\hline
\end{tabular}




\begin{tabular}{|c|l|l|}
\hline & Bank penerbit. & $\begin{array}{l}\text { tergantung dari rekening bank } \\
\text { penerbit dan agen atau reseller. }\end{array}$ \\
\hline 11 & Keamanan lebih terjamin. & $\begin{array}{l}\text { Keamanan tidak terjamin terutama } \\
\text { penerbit uang virtual yang tidak } \\
\text { memiliki izin dari Bank sentral dari } \\
\text { suatu Negara. }\end{array}$ \\
\hline 12 & $\begin{array}{l}\text { Tidak dijamin oleh Lembaga } \\
\text { Penjamin Simpanan (LPS). }\end{array}$ & $\begin{array}{l}\text { Tidak dijamin oleh Lembaga } \\
\text { Penjamin Simpanan (LPS). }\end{array}$ \\
\hline 13 & $\begin{array}{l}\text { Tidak memerlukan otorisasi on- } \\
\text { line, tanda tangan maupun PIN. }\end{array}$ & $\begin{array}{l}\text { Memerlukan otorisasi on-line, } \\
\text { password dan PIN transaksi. }\end{array}$ \\
\hline 14 & $\begin{array}{l}\text { Menggunakan mata uang Negera } \\
\text { Penerbit. }\end{array}$ & $\begin{array}{l}\text { Kebanyakan menggunakan mata uang } \\
\text { Dollar dan Euro sebagai pilihan } \\
\text { kedua. }\end{array}$ \\
\hline 15 & $\begin{array}{l}\text { Tidak ada biaya setiap transaksi, } \\
\text { kecuali yang menggunakan ponsel } \\
\text { pulsanya akan berkurang setiap } \\
\text { transaksi. }\end{array}$ & $\begin{array}{l}\text { Terdapat biaya dalam transaksi } \\
\text { terutama transaksi penarikan dana. }\end{array}$ \\
\hline
\end{tabular}

\section{Kelebihan dan Kekurangan Uang Elektronik dan Uang Virtual}

Setiap produk yang dikeluarkan oleh Bank atau lembaga keuangan pasti ada kelebihan dan kekurangannya. Begitu juga dengan uang elektronik dan uang virtual memiliki kelebihan dan kekurangan.

a. Kelebihan uang elektronik:

- Lebih praktis, cepat, fleksibel dan nyaman dibandingkan dengan uang tunai.

- Media yang digunakan tidak memerlukan tempat seperti uang tunai karena berbentuk kartu atau ponsel yang gampang dibawa kemanakemana.

- Tidak memerlukan tanda tangan atau PIN dalam transaksi sehingga tidak membutuhkan waktu lama.

- Tidak membutuhkan uang kembalian dalam bentuk uang recehan, karena setiap transaksi akan langsung terpotong pada uang elektronik.

- Saldo maksimal dibatasi hanya sampai Rp. 5 juta, ini bisa memperkecil resiko ketika uang elektronik hilang atau dicuri sehingga batas maksimal kerugian adalah Rp. 5 juta.

b. Kekurangan uang elektronik:

- Ketika kartu atau ponsel uang elektronik hilang atau dicuri orang maka otomatis uang elektronik tidak bisa diselamatkan nominalnya, karena dana sepenuhnya dalam kuasa pemegang uang elektronik kemudian tidak ada otorisasi online atau PIN.

- Tidak bisa digunakan disemua tempat transaksi keuangan seperti halnya uang tunai, karena hanya bisa digunakan pada merchantmerchant yang sudah bekerjasama dengan penerbit uang elekronik dan biasanya banyak tersedia dikota-kota besar.

- Tidak dijamin oleh lembaga penjamin simpanan (LPS). 
c. Kelebihan uang virtual:

- Bisa digunakan untuk transaksi keuangan online di Internet dan lintas Negara tanpa perlu mentransfer atau kliring uang melalui rekening bank.

- Untuk mengisi dana pada uang virtual bisa ditransfer dari banyak bank, tinggal dipilih sesuai dengan rekening bank yang dipunyai oleh pelanggan.

- Website uang virtual sudah dilengkapi dengan data security (SSL), sehingga bisa dikatakan aman dalam bertransaksi.

- Tidak ada pembatasan saldo maksimal.

d. Kekurangan uang virtual:

- Semakin banyak nominal uang pada uang virtual makin tinggi resiko yang akan ditanggung, karena tidak ada jaminan dari lembaga penjamin simpanan (LPS). Ketika penerbit uang virtual menutup website atau melarikan diri maka hilanglah uang yang tersimpan dalam uang virtual.

- Terdapat penyalahgunaan uang virtual karena bisa digunakan antar lintas Negara, bentuk penyalahgunaannya bisa seperti pencucian uang hasil korupsi, jual beli narkoba dan sebagainya.

- Sewaktu melakukan transaksi belanja online atau melakukan kegiatan money game atau kegiatan lainnya yang menggunakan uang virtual terdapat pihak-pihak yang melakukan penipuan melalui aplikasi uang virtual palsu dimana sewaktu melakukan transaksi transfer atau pembayaran menggunakan aplikasi uang virtual, data otorisasi dan PIN transaksi direkam sehingga data otorisasi dan PIN transaksi tersebut digunakan untuk menguras nominal uang yang ada didalam uang virtual.

- Ketika ada permasalahan seperti penerbit melarikan diri atau melakukan penipuan atau tertipu sewaktu melakukan transaksi belanja online dan sebagainya maka nasabah atau pelanggan akan susah memperkarakan secara hukum, karena sudah melibatkan hukum lintas Negara, kecuali pelanggan dan penerbit uang virtual pada Negara yang sama.

\section{Kesimpulan}

Adapun kesimpulan dan saran yang dapat diberikan dari makalah ini adalah sebagai berikut:

a. Penggunaan uang elektronik dan uang virtual di Indonesia semakin meningkat, ini dibuktikan makin tingginya peredaran dan transaksi uang elektronik serta makin banyaknya website-website uang virtual yang bermunculan di Internet yang menawarkan kemudahan dalam bertransaksi menggunakan uang virtual.

b. Seseorang yang mempunyai mobilitas tinggi sangat membutuhkan kepraktisan dalam transaksi keuangan, uang elektronik merupakan salah satu fasilitas yang disediakan oleh lembaga keuangan untuk membantu 
kepraktisan dalam bertransaksi keuangan karena tidak perlu mengeluarkan uang tunai.

c. Dalam menggunakan uang elektronik diminta kepada para penggunanya agar berhati-hati dalam menjaga uang elektronik, karena ketika uang elektronik jatuh ketangan orang yang tidak bertanggung jawab, maka nominal dalam uang elektronik akan hilang dicuri sebab uang elektronik tidak membutuhkan otoritas online dan PIN.

d. Uang elektronik merupakan salah satu program pemerintah Indonesia dalam mengurangi penggunaan uang tunai.

e. Uang virtual merupakan salah satu fasilitas keuangan non tunai yang disediakan di Internet, yang digunakan untuk bertransaksi keuangan lintas Negara secara online.

f. Dalam menggunakan uang virtual diminta kepada para penggunanya agar bijak dan sangat berhati-hati dalam menggunakan uang virtual, karena di Internet banyak sekali website-website yang melakukan penipuan terhadap penggunaan uang virtual secara tersembunyi melalui aplikasi uang virtual palsu.

g. Penggunaan uang elektronik dan uang virtual belum dapat sepenuhnya menggantikan peran dan kegunaan dari uang tunai di Indonesia.

\section{DAFTAR PUSTAKA}

Burhanuddin Abdullah, 2006. Paper Seminar International Toward a Less Cash Society in Indonesia. Jakarta: Direktorat Akunting dan Sistem pembayaran Bank Indonesia.

Dewi Rachmat Kusuma, dalam http://finance.detik.com/read/2014/08/20/180359/ 2667868/5/masyarakat-bisa-pakai-uang-elektronik-maksimal-rp-20-jutasebulan. Diakses tanggal 19 Maret 2016.

European Central Bank, 1998, Report On Electronic Money, Frankfurt: European Central Bank.

Peraturan Bank Indonesia Nomor 16/8/PBI/2014, Tentang Perubahan Atas Peraturan Bank Indonesia Nomor 11/12/PBI/2009 Tentang Uang Elekronik (Electronic Money), ditetapkan di Jakarta pada tanggal 8 April 2014.

Septiano Pratama, http://www.bank-indo.com/pengertian-uang-elektronik-danmacam-bank-penyedianya/. Diakses tanggal 17 Maret 2016.

Siti Hidayati, dkk., 2006, Operasional E-Money, Jakarta: BI.

Surat Edaran Bank Indonesia Nomor 11/11/DASP, Perihal Uang Elektronik, Jakarta: BI, tertanggal 13 April 2009.

Tim Inisiatif Bank Indonesia, 2006, Working Paper: Upaya Meningkatkan Penggunaan Alat Pembayaran Non Tunai Melalui Pengembangan EMoney, Jakarta: BI. 
Veithal Rivai, dkk., 2001, Bank and Financial Institution Management, Jakarta: PT. Raja Grafindo Persada.

http://www.artajasa.co.id/. Diakses tanggal 21 Maret 2016

http://www.bankdki.co.id/. Diakses tanggal 19 Maret 2016

http://www.bankmandiri.co.id/. Diakses tanggal 19 Maret 2016

http://www.bca.co.id/. Diakses tanggal 19 Maret 2016

http://www.bi.go.id/. Diakses tanggal 23 Maret 2016

http://www.bni.co.id/. Diakses tanggal 20 Maret 2016

http://www.bri.co.id/. Diakses tanggal 20 Maret 2016

http://www.finnet-indonesia.com/home/. Diakses tanggal 20 Maret 2016

http://www.nobubank.com/. Diakses tanggal 21 Maret 2016

http://www.ponselpay.com/. Diakses tanggal 21 Maret 2016

http://www.skye.co.id/. Diakses tanggal 20 Maret 2016

http://www.telkomsel.com/. Diakses tanggal 19 Maret 2016

http://www.tmoney.co.id/. Diakses tanggal 19 Maret 2016

http://www.uangku.co.id/. Diakses tanggal 21 Maret 2016

http://www.xl.co.id/. Diakses tanggal 20 Maret 2016

https://plus.dompetku.com/. Diakses tanggal 20 Maret 2016

https://www.bankmega.com/. Diakses tanggal 20 Maret 2016

https://www.cimbniaga.com/. Diakses tanggal 21 Maret 2016

https://www.permatabank.com/. Diakses tanggal 21 Maret 2016

https://www.truemoney.co.id/. Diakses tanggal 21 Maret 2016 